\title{
MOR and MOE of Serbian Spruce (Picea omorika Pančić/Purkyně) Wood from Natural Stands
}

\section{Modul loma i modul elastičnosti drva omorike (Picea omorika Pančić/Purkyně) iz prirodnih sastojina}

\author{
Original scientific paper • Izvorni znanstveni rad \\ Received-prispjelo: 23. 6. 2020. \\ Accepted-prihvaćeno: 14. 1. 2021. \\ UDK: $630 * 812.71$ \\ https://doi.org/10.5552/drvind.2021.2028
}

(C) 2021 by the author(s). Licensee Faculty of Forestry and Wood Technology, University of Zagreb. This article is an open access article distributed under the terms and conditions of the Creative Commons Attribution (CC BY) license.

\begin{abstract}
The paper presents the results of testing the bending stress of Serbian spruce wood from natural stands. In testing the samples, in addition to the modulus of rupture, the bending stress at the proportionality limit, the ratio between the stress at the proportionality limit and the modulus of rupture as well as the modulus of elasticity of wood were determined. The study included nine trees from natural stands, and a total of 261 samples were tested. Regression analysis determined the dependences of these mechanical properties on the annual ring width, the proportion of late wood and wood density, as well as the dependence of the modulus of elasticity on the modulus of rupture.
\end{abstract}

Keywords: Picea omorika; modulus of rupture; modulus of elasticity; natural stands

SAŽETAK • U radu su prikazani rezultati ispitivanja naprezanja pri savijanju drva Pančićeve omorike podrijetlom iz prirodnih sastojina. Osim modula loma, pri ispitivanju uzoraka utvrđeni su i savojno naprezanje u točki proporcionalnosti, odnos čvrstoće na savijanje u točki proporcionalnosti i modula loma, kao i modul elastičnosti drva. Istraživanje je obuhvatilo devet stabala iz prirodnih sastojina, a ispitan je ukupno 261 uzorak. Regresijskom su analizom utvrđeni odnosi navedenih mehaničkih svojstava i širine goda, udjela kasnog drva i gustoće drva, kao i odnos modula elastičnosti i modula loma.

Ključne riječi: Picea omorika; modul loma; modul elastičnosti; prirodne sastojine

\section{INTRODUCTION \\ 1. UVOD}

Serbian spruce (Picea omorika Pančić/Purkyně) is naturally distributed in Bosnia and Herzegovina and Serbia in the area around the middle and lower reaches of the Drina River. It is found on steep, rocky cliffs, mostly on limestone, rarely serpentine, at altitudes of 300 to 1700 m (Vidaković and Franjić, 2004).

Serbian spruce is interesting from many aspects, both to the science and profession, and to the general public. A large number of scientific and professional papers deal with various issues related to Serbian

\footnotetext{
${ }^{1}$ Authors are assistant professor and associate professor at University of Banja Luka, Faculty of Forestry, 78000 Banja Luka, Bosnia and Herzegovina.

${ }^{2}$ Authors are full professor and associate professor at University of Belgrade, Faculty of Forestry, Belgrade, Serbia.
} 
spruce, ranging from its distribution, the configuration of the terrain as well as the habitat where it occurs (Fukarek, 1935, 1950; Čolić, 1953, 1957) to the latest genetic research (Aleksić and Geburek, 2010, 2014; Mataruga et al., 2020). However, it is very difficult to find information in the literature concerning the mechanical properties of Serbian spruce wood, especially the wood originating from natural stands. LukićSimonović (1970) investigated in more detail the mechanical properties of Serbian spruce from its natural stands in western Serbia, while no such research has been done in Bosnia and Herzegovina.

Modulus of rupture (MOR) and modulus of elasticity $(M O E)$ are among the most important parameters for determining the wood quality, especially for the usage of wood in construction (Bodig and Jayne, 1982). The modulus of elasticity, as a measure of stiffness, can be used to estimate strength because there is a positive correlation between stiffness and strength (Panshin and de Zeeuw, 1980). Popović (1990) states that the ratio between the bending stress at the proportionality limit and the modulus of rupture is a very important fact in the practical application of wood, where, if this ratio is known, the use of loads exceeding these values and leading to permanent deformation or fracture can be prevented.

Knowledge of the stress at the proportionality limit, maximum stress and their ratio, as well as the knowledge of the effect of certain factors on the specified bending characteristics has both scientific and practical significance. These factors are very important for designing the bending tools and for determination the stress that products can be exposed to during use (Svoboda et al., 2017).

\section{MATERIALS AND METHODS 2. MATERIJALI I METODE}

The material for the research comes from three localities of the natural stands of Serbian spruce managed by the FE Panos - Višegrad. These are Gostilja (GO), Stolac 1 (S1) and Stolac 2 (S2). Location GO is at $1130 \mathrm{~m}$ above sea level, and the total area of this stand is 25.8 ha. S1 is located at $1200 \mathrm{~m}$ above sea level, and S2 at $960 \mathrm{~m}$ above sea level, while the total area of the stands is 29.5 ha.

According to Mataruga et al. (2011), Serbian spruce has been listed as an endangered plant species from 2010. Considering that, the selection of trees was taken into account when planning the research so that the relevant information was obtained with a minimum

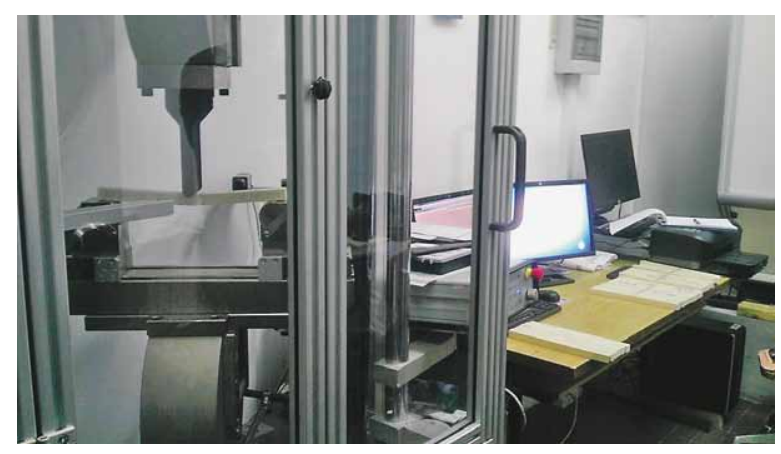

Figure 1 Bending testing

Slika 1. Ispitivanje svojstava pri savijanju

number of trees. From each locality, three trees were selected and harvested, and the average values of their characteristics by locations are given in Table 1 .

Three logs, $1.2 \mathrm{~m}$ long, were cut from each tree. One log was taken from a height of $1.3 \mathrm{~m}$, one from the part of the bole just below the first green branch, and one log was taken from the height in the middle between the two mentioned heights. From them, $30 \mathrm{~mm}$ thick radial planks were cut, out of which, after natural drying for three months and processing on the thickener, they were reduced to a thickness of $20 \mathrm{~mm}$. From them, samples $(20 \mathrm{~mm} \times 20 \mathrm{~mm} \times 320 \mathrm{~mm})$ for bending testing were made. The test was performed at the Material Testing Laboratory at the Faculty of Mechanical Engineering, University of Banja Luka, using a Messphysik "Beta 200", a universal testing machine used to test mechanical properties of different types of materials specialized in the testing of materials (Figure 1). The ISO 3133:1975 standard was used for bending testing.

For this test, 261 samples were selected. During selection, samples that are closest to the pith and that have natural defects were avoided. Before testing, the mass and dimensions in radial, tangential and axial directions of samples were measured. These data were used to calculate the wood density at the time of testing using Eq. 1:

Where:

$$
\rho=\frac{m}{T \cdot R \cdot A} \cdot 1000\left(\frac{g}{\mathrm{~cm}^{3}}\right)
$$

$m$ - sample mass at the time of testing $(\mathrm{g})$

$T, R, A$-sample dimensions in tangential, radial and axial direction at the time of testing $(\mathrm{mm})$

The samples were scanned in cross-section in order to determine the average annual ring width and the average proportion of late wood, using CDendro 7.6 and CooRecorder 7.6. Three-point bending tests were carried out to investigate the static behavior of sam-

Table 1 Average values of characteristics of Serbian spruce trees

Tablica 1. Prosječne vrijednosti svojstava stabala Pančićeve omorike

\begin{tabular}{|c|c|c|c|c|}
\hline \multirow{2}{*}{$\begin{array}{c}\text { Location } \\
\text { Lokalitet }\end{array}$} & \multicolumn{4}{|c|}{ Characteristics of trees / Svojstva stabala } \\
\cline { 2 - 5 } & $\begin{array}{c}\text { Number of rings at } \mathbf{0 . 3} \mathbf{~ m} \\
\text { Broj godova na 0,3 m }\end{array}$ & $\begin{array}{c}\text { Diameter at brest height, cm } \\
\text { Prsni promjer, } \mathrm{cm}\end{array}$ & $\begin{array}{c}\text { Tree height, } \mathbf{m} \\
\text { Visina stabla, } \mathbf{m}\end{array}$ & $\begin{array}{c}\text { Trunk length, } \mathbf{m} \\
\text { Duljina debla, } \mathrm{m}\end{array}$ \\
\hline GO & 112 & 29.13 & 22.2 & 18.5 \\
\hline S1 & 131 & 30.00 & 28.4 & 24.4 \\
\hline S2 & 128 & 30.97 & 25.8 & 20.7 \\
\hline $\begin{array}{c}\text { Average value } \\
\text { Prosječna vrijednost }\end{array}$ & 124 & 30.03 & 25.4 & 21.2 \\
\hline
\end{tabular}


ples. Samples were placed so that they were on one radial side and the distance between the supports was $280 \mathrm{~mm}$. The loading speed was set to $10 \mathrm{~mm} / \mathrm{min}$. Load-deflection graphs were obtained by testing and they were used to obtain the values of bending stress at the proportionality limit, MOR and MOE. The calculation formulas for MOR (Eq. 2) and bending stress at the proportionality limit (Eq. 3) are:

$$
\begin{gathered}
\sigma_{s}=\frac{3 \cdot F_{\max } \cdot l}{2 \cdot b \cdot h^{2}}(\mathrm{MPa}) \\
\sigma_{\mathrm{sp}}=\frac{3 \cdot F_{\mathrm{p}} \cdot l}{2 \cdot b \cdot h^{2}}(\mathrm{MPa})
\end{gathered}
$$

Where:

$F_{\text {max }}-$ maximum load (N)

$F_{\mathrm{p}}-$ load at proportionality limit (N)

$l$ - distance between supports $(\mathrm{mm})$

$b$ - width of the sample $(\mathrm{mm})$

$h$ - height of the sample (mm)

The calculation formula for $M O E$ is:

Where:

$$
E_{\mathrm{s}}=\frac{F \cdot l^{3}}{4 \cdot b \cdot h^{3} \cdot f}(\mathrm{MPa})
$$

$F-$ load from elastic zone (N)

$l$ - distance between supports ( $\mathrm{mm})$

$b$ - width of the sample $(\mathrm{mm})$

$h$ - height of the sample $(\mathrm{mm})$

$f$ - deflection (mm).

The calculation formula for the ratio between the bending stress at the proportionality limit and MOR is:

$$
P_{\sigma}=\frac{\sigma_{\mathrm{sp}}}{\sigma_{\mathrm{s}}} \cdot 100(\%)
$$

After the test, all samples were weighed and then dried to an oven dry state to determine moisture content at the time of testing using Eq. 6:

$$
v_{\mathrm{a}}=\frac{m-m_{0}}{m_{0}} \cdot 100(\%)
$$

Where:

$m$ - sample mass at the time of testing $(\mathrm{g})$

$m_{\mathrm{o}}$ - sample mass in oven dry state $(\mathrm{g})$

In order to compare the obtained values of $M O R$ and $M O E$ with literature data, results of bending test were reduced to values at standard moisture content (12\%) using Eq. 7:

$$
\sigma_{\mathrm{s} 12}\left(E_{\mathrm{sv}}\right)=\sigma_{\mathrm{sv}}\left(E_{\mathrm{sv}}\right) \cdot\left[1+0.02 \cdot\left(v_{\mathrm{a}}-12\right)\right](\mathrm{MPa})
$$

\section{RESULTS AND DISCUSSION 3. REZULTATI I RASPRAVA}

The average values of wood density and moisture content at the time of testing the samples from all three locations are given in Table 2 . The average density of investigated Serbian spruce wood is $0.517 \mathrm{~g} /$ $\mathrm{cm}^{3}$ at a moisture content of $15 \%$, while the average value of Serbian spruce wood density investigated by Lukić-Simonović (1955), from the territory of Serbia, at the same moisture content, was $0.482 \mathrm{~g} / \mathrm{cm}^{3}$. The average annual ring width of investigated Serbian spruce wood is $1.76 \mathrm{~mm}$ and the average proportion of late wood is $15.24 \%$.

Table 3 shows the average values and other statistical indicators of $M O R$ at standard moisture content by locations. Trees from GO have the lowest average values of MOR (84.23 MPa), and trees from S1 the largest (94.86 MPa). The smallest variation in $M O R$ was found at S2 (12.19\%) and the largest at GO (16.17\%).

The average value of $M O R$ at all locations $(89.72$ $\mathrm{MPa}$ ) is slightly lower than the MOR at standard moisture content obtained in research by Lukić-Simonović (1970), namely 96.7 MPa. Studying the MOR of Serbian spruce wood from plantations in Germany, Kommert (1993) found that its average values at moisture content of $12 \%$ are in the range of $57.6 \mathrm{MPa}$ (average density of samples is $0.424 \mathrm{~g} / \mathrm{cm}^{3}$ ) to $86 \mathrm{MPa}$ (average density of samples is $0.510 \mathrm{~g} / \mathrm{cm}^{3}$ ).

As the number of studies on the mechanical properties of Serbian spruce wood is limited, comparison with the mechanical properties of spruce wood was made. According to Karahasanović (1992), the MOR of spruce at a moisture content of $(12 \pm 3) \%$ is 64 MPa. Gorišek et al. (2004) stated that the average MOR of spruce from Slovenia is 77.4 MPa, while Pushinskis et al. (2002) tested spruce from western Latvia and found that the average MOR is $106.42 \mathrm{MPa}$.

In addition to the $M O R$, the bending stress at the proportionality limit was determined, as well as the ratio between the bending stress at the proportionality limit and MOR. The obtained values are shown in Table 4 and 5 .

The average bending stress at the proportionality limit for all three locations is $44.72 \mathrm{MPa}$, while the coefficient of variation is $15.92 \%$. The average ratio of

Table 2 Average values of annual rings width, proportion of late wood, density and moisture content of wood at the moment of testing

Tablica 2. Prosječne vrijednosti širine goda, udio kasnog drva, gustoće i sadržaja vode u drvu u trenutku ispitivanja

\begin{tabular}{|c|c|c|c|c|c|c|c|}
\hline \multirow{2}{*}{$\begin{array}{c}\text { Location } \\
\text { Lokalitet }\end{array}$} & $\boldsymbol{a} \boldsymbol{w} \boldsymbol{w}$ & $\boldsymbol{p} \boldsymbol{w} \boldsymbol{w}$ & \multirow{2}{*}{$\boldsymbol{n}$} & $\boldsymbol{v}_{\mathrm{a}}$ & \multicolumn{3}{|c|}{$\boldsymbol{\rho}$} \\
\cline { 2 - 6 } & $A V, \mathrm{~mm}$ & $A V, \%$ & & $A V, \%$ & $A V, \mathrm{~g} / \mathrm{cm}^{3}$ & $S D, \%$ & $C V, \%$ \\
\hline $\mathrm{S} 1$ & 1.66 & 15.64 & 88 & 14.77 & 0.534 & 0.035 & 6.61 \\
\hline $\mathrm{S} 2$ & 1.68 & 15.44 & 83 & 15.15 & 0.509 & 0.024 & 4.62 \\
\hline $\mathrm{GO}$ & 1.90 & 14.80 & 90 & 15.30 & 0.508 & 0.028 & 5.54 \\
\hline & 1.76 & 15.24 & 261 & 15.07 & 0.517 & 0.032 & 6.12 \\
\hline
\end{tabular}

$n$ - number of tested samples / broj testiranih uzoraka; $\mathrm{v}_{\mathrm{a}}$ - moisture content at the moment of testing / sadržaj vode u trenutku ispitivanja; arw - annual ring width / širina goda; plw - proportion of late wood / udio kasnog drva; $\rho$-density of wood at the moment of testing / gustoća drva u trenutku ispitivanja; $A V$ - average value / prosječna vrijednost; $S D$ - standard deviation / standardna devijacija; CV - coefficient of variation / koeficijent varijacije 
Table 3 Statistical analysis of $M O R$ of Serbian spruce from three different stem heights

Tablica 3. Statistička analiza modula loma Pančićeve omorike na uzorcima s tri različite visine debla

\begin{tabular}{|c|c|c|c|c|c|c|c|}
\hline \multirow{2}{*}{$\begin{array}{l}\text { Location } \\
\text { Lokalitet }\end{array}$} & \multirow{2}{*}{$\begin{array}{c}\text { Height of stem } \\
\text { Visina debla }\end{array}$} & \multirow{2}{*}{$n$} & \multicolumn{5}{|c|}{$\sigma_{s}$} \\
\hline & & & $A V, \mathrm{MPa}$ & $-95, \mathrm{MPa}$ & $+95, \mathrm{MPa}$ & $S D, \mathrm{MPa}$ & $C V, \%$ \\
\hline \multirow{4}{*}{$\mathrm{S} 1$} & $\mathrm{I}$ & 30 & 94.97 & 90.55 & 99.39 & 11.84 & 12.47 \\
\hline & II & 30 & 95.82 & 90.65 & 100.99 & 13.84 & 14.44 \\
\hline & III & 28 & 94.47 & 90.05 & 98.89 & 11.40 & 12.07 \\
\hline & & 88 & 95.10 & 92.50 & 97.71 & 12.30 & 12.93 \\
\hline \multirow{4}{*}{ S2 } & I & 25 & 84.61 & 78.37 & 90.84 & 15.11 & 17.86 \\
\hline & II & 31 & 94.61 & 92.46 & 96.76 & 5.87 & 6.20 \\
\hline & III & 27 & 89.59 & 86.09 & 93.08 & 8.84 & 9.87 \\
\hline & & 83 & 89.96 & 87.56 & 92.37 & 11.01 & 12.24 \\
\hline \multirow{5}{*}{ GO } & I & 30 & 84.00 & 78.62 & 89.37 & 14.39 & 17.13 \\
\hline & II & 30 & 84.13 & 80.40 & 87.87 & 9.99 & 11.88 \\
\hline & III & 30 & 84.55 & 78.50 & 90.60 & 16.20 & 19.16 \\
\hline & & 90 & 84.23 & 81.37 & 87.08 & 13.62 & 16.17 \\
\hline & & 261 & 89.72 & 88.12 & 91.32 & 13.14 & 14.64 \\
\hline
\end{tabular}

$\sigma_{\text {s }}$ - modulus of rupture, MOR / modul loma; $n$ - number of tested samples / broj testiranih uzoraka; AV-average value / prosječna vrijednost; -95 - lower boundary of estimation interval with a probability of $95 \%$ / donja granica intervala procjene s vjerojatnošcu od $95 \%$; +95 - upper boundary of estimation interval with a probability of $95 \%$ / gornja granica intervala procjene s vjerojatnošć od $95 \%$; SD - standard deviation / standardna devijacija; $C V$ - coefficient of variation / koeficijent varijacije

the bending stress at the proportionality limit for all tested samples is $50.18 \%$ of the maximum bending stress, while the variation is $12.73 \%$. Popović (1990) states that the bending stress at the proportionality limit for beech wood is on average $54.4 \%$ and $56 \%$ in the radial and tangential direction, respectively, from the value of the maximum bending stress.

Table 6 shows the average values of modulus of elasticity $(M O E)$ at standard moisture content as well as other statistical parameters. The lowest average value of $M O E$ was found in trees from GO (10953.99 $\mathrm{MPa})$, and the highest in trees from S2 (12161.92 $\mathrm{MPa})$. The smallest variation of $M O E$ is at $\mathrm{S} 2(9.83 \%)$ and the largest at S1 (21.46\%).

According to Šoškić and Popović (2002), the average value of $M O E$ for spruce is $11000 \mathrm{MPa}$, which is approximately the value of $M O E$ for Serbian spruce obtained in this study (11566.23 MPa). Johansson and Kliger (2000) state that the average value of MOE determined from bending for spruce is $12500 \mathrm{MPa}$, according to Aanerød (2014) $12800 \mathrm{MPa}$, with a coefficient of variation of $19.5 \%$, while according to Pushinskis et al. (2002) it is $13660 \mathrm{MPa}$.

Analysis of the variance of $M O R$ showed that there is statistically significant difference between the locations, while there is no difference between the locations in the ratio between bending stress at the proportionality limit and MOR. Using the Duncan test in the analysis of the variance of MOE, the locations were classified into two homogeneous groups, i.e. it was noticed that there is no statistically significant difference between the locations S1 and S2. In the analysis of the variance of the bending stress at the proportionality limit, locations were classified into two homogeneous

Table 4 Statistical analysis of bending stress at proportionality limit of Serbian spruce from three different stem heights Tablica 4. Statistička analiza savojnog naprezanja u točki proporcionalnosti Pančićeve omorike na uzorcima s tri različite visine debla

\begin{tabular}{|c|c|c|c|c|c|c|c|}
\hline \multirow{2}{*}{$\begin{array}{l}\text { Location } \\
\text { Lokalitet }\end{array}$} & \multirow{2}{*}{$\begin{array}{l}\text { Height of stem } \\
\text { Visina debla }\end{array}$} & \multirow{2}{*}{$n$} & \multicolumn{5}{|c|}{$\sigma_{\text {sp }}$} \\
\hline & & & $A V, \mathrm{MPa}$ & $-95, \mathrm{MPa}$ & $+95, \mathrm{MPa}$ & $S D, \mathrm{MPa}$ & $C V, \%$ \\
\hline \multirow{4}{*}{ S1 } & $\mathrm{I}$ & 30 & 49.67 & 47.04 & 52.31 & 7.06 & 14.20 \\
\hline & II & 30 & 47.10 & 44.00 & 50.20 & 8.30 & 17.63 \\
\hline & III & 28 & 47.85 & 46.14 & 49.55 & 4.40 & 9.20 \\
\hline & & 88 & 48.21 & 46.76 & 49.66 & 6.84 & 14.19 \\
\hline \multirow{4}{*}{ S2 } & $\mathrm{I}$ & 25 & 42.73 & 40.27 & 45.20 & 5.98 & 13.99 \\
\hline & II & 31 & 45.45 & 43.57 & 47.33 & 5.13 & 11.29 \\
\hline & III & 27 & 42.78 & 40.45 & 45.11 & 5.89 & 13.78 \\
\hline & & 83 & 43.76 & 42.51 & 45.01 & 5.73 & 13.09 \\
\hline \multirow{5}{*}{ GO } & $\mathrm{I}$ & 30 & 41.17 & 38.64 & 43.70 & 6.77 & 16.45 \\
\hline & II & 30 & 41.47 & 38.77 & 44.16 & 7.22 & 17.41 \\
\hline & III & 30 & 43.89 & 41.03 & 46.76 & 7.67 & 17.46 \\
\hline & & 90 & 42.18 & 40.66 & 43.70 & 7.25 & 17.19 \\
\hline & & 261 & 44.72 & 43.85 & 45.58 & 7.12 & 15.92 \\
\hline
\end{tabular}

$\sigma_{\mathrm{sp}}$ - bending stress at proportionality limit / savojno naprezanje u točki proporcionalnosti, $n$ - number of tested samples / broj testiranih uzoraka; $A V$ - average value / prosječna vrijednost; -95 - lower boundary of estimation interval with a probability of $95 \%$ / donja granica intervala procjene s vjerojatnošću od $95 \%$; +95 - upper boundary of estimation interval with a probability of $95 \%$ / gornja granica intervala procjene s vjerojatnošću od $95 \% ; S D$ - standard deviation / standardna devijacija; $C V$ - coefficient of variation / koeficijent varijacije 
Table 5 Statistical analysis of ratio between bending stress at proportionality limit and MOR of Serbian spruce from three different stem heights

Tablica 5. Statistička analiza odnosa savojnog naprezanja u točki proporcionalnosti i modula loma Pančićeve omorike na uzorcima s tri različite visine debla

\begin{tabular}{|c|c|c|c|c|c|c|c|}
\hline \multirow{2}{*}{$\begin{array}{l}\text { Location } \\
\text { Lokalitet }\end{array}$} & \multirow{2}{*}{$\begin{array}{c}\text { Height of stem } \\
\text { Visina debla }\end{array}$} & \multirow{2}{*}{$n$} & \multicolumn{5}{|c|}{$P_{\sigma}, \%$} \\
\hline & & & $A V$ & -95 & +95 & $S D$ & $\mathrm{CV}$ \\
\hline \multirow{4}{*}{ S1 } & I & 30 & 52.35 & 50.82 & 53.87 & 4.08 & 7.80 \\
\hline & II & 30 & 49.16 & 47.41 & 50.92 & 4.70 & 9.57 \\
\hline & III & 28 & 51.14 & 48.92 & 53.36 & 5.73 & 11.20 \\
\hline & & 88 & 50.88 & 49.82 & 51.94 & 4.99 & 9.81 \\
\hline \multirow{4}{*}{$\mathrm{S} 2$} & $\mathrm{I}$ & 25 & 51.61 & 48.00 & 55.22 & 8.75 & 16.95 \\
\hline & II & 31 & 48.01 & 46.49 & 49.53 & 4.15 & 8.64 \\
\hline & III & 27 & 47.82 & 45.77 & 49.87 & 5.18 & 10.84 \\
\hline & & 83 & 49.03 & 47.65 & 50.42 & 6.33 & 12.92 \\
\hline \multirow{5}{*}{ GO } & $\mathrm{I}$ & 30 & 49.53 & 46.85 & 52.20 & 7.16 & 14.45 \\
\hline & II & 30 & 49.50 & 46.51 & 52.49 & 8.00 & 16.17 \\
\hline & III & 30 & 52.67 & 50.04 & 55.31 & 7.07 & 13.42 \\
\hline & & 90 & 50.57 & 49.00 & 52.14 & 7.49 & 14.81 \\
\hline & & 261 & 50.18 & 49.41 & 50.96 & 6.39 & 12.73 \\
\hline
\end{tabular}

$P_{\sigma}$ - ratio between bending stress at proportionality limit and MOR / odnos savojnog naprezanja u točki proporcionalnosti $i$ modula loma; $n$ - number of tested samples / broj testiranih uzoraka; $A V$ - average value / prosječna vrijednost; -95 - lower boundary of estimation interval with a probability of $95 \%$ / donja granica intervala procjene s vjerojatnošć od $95 \%$; +95 - upper boundary of estimation interval with a probability of $95 \%$ / gornja granica intervala procjene s vjerojatnošću od $95 \%$; SD - standard deviation / standardna devijacija; CV - coefficient of variation / koeficijent varijacije

Table 6 Statistical analysis of $M O E$ of Serbian spruce from three different stem heights

Tablica 6. Statistička analiza modula elastičnosti Pančićeve omorike na uzorcima s tri različite visine debla

\begin{tabular}{|c|c|c|c|c|c|c|c|}
\hline \multirow{2}{*}{$\begin{array}{l}\text { Location } \\
\text { Lokalitet }\end{array}$} & \multirow{2}{*}{$\begin{array}{c}\text { Height of stem } \\
\text { Visina debla }\end{array}$} & \multirow{2}{*}{$n$} & \multicolumn{5}{|c|}{$E_{\mathrm{s}}$} \\
\hline & & & $A V, \mathrm{MPa}$ & $-95, \mathrm{MPa}$ & $+95, \mathrm{MPa}$ & $S D, \mathrm{MPa}$ & $C V, \%$ \\
\hline \multirow{4}{*}{ S1 } & $\mathrm{I}$ & 24 & 11267.32 & 10400.02 & 12134.63 & 2053.95 & 18.23 \\
\hline & II & 27 & 12182.87 & 11216.82 & 13148.92 & 2442.07 & 20.05 \\
\hline & III & 26 & 11442.37 & 10597.84 & 12286.91 & 2090.90 & 18.27 \\
\hline & & 77 & 11647.47 & 11144.18 & 12150.76 & 2529.33 & 21.46 \\
\hline \multirow{4}{*}{$\mathrm{S} 2$} & I & 25 & 11699.33 & 11118.42 & 12280.24 & 1407.31 & 12.03 \\
\hline & II & 30 & 12625.86 & 12240.59 & 13011.12 & 1031.75 & 8.17 \\
\hline & III & 27 & 12074.75 & 11684.79 & 12464.71 & 985.78 & 8.16 \\
\hline & & 82 & 12161.92 & 11899.33 & 12424.50 & 1195.06 & 9.83 \\
\hline \multirow{5}{*}{ GO } & I & 30 & 10674.33 & 10053.79 & 11294.88 & 1661.86 & 15.57 \\
\hline & II & 30 & 10879.25 & 10313.77 & 11444.72 & 1514.37 & 13.92 \\
\hline & III & 30 & 11308.40 & 10649.02 & 11967.78 & 1765.85 & 15.62 \\
\hline & & 90 & 10953.99 & 10607.69 & 11300.29 & 1653.42 & 15.09 \\
\hline & & 249 & 11566.23 & 11342.61 & 11789.85 & 1791.57 & 15.49 \\
\hline
\end{tabular}

$E_{\mathrm{s}}$ - modulus of elasticity $(M O E)$ / modul elastičnosti, $n$ - number of tested samples / broj testiranih uzoraka; $A V$ - average value / prosječna vrijednost; - 95 - lower boundary of estimation interval with a probability of $95 \%$ / donja granica intervala procjene s vjerojatnošću od $95 \%$; +95 - upper boundary of the estimation interval with a probability of $95 \%$ / gornja granica intervala procjene s vjerojatnošću od $95 \% ; S D$ standard deviation / standardna devijacija; $C V$ - coefficient of variation / koeficijent varijacije

Table 7 Analysis of variation of $M O R, M O E$, bending stress at proportionality limit, ratio between bending stress at proportionality limit and $M O R$

Tablica 7. Analiza varijance modula loma, modula elastičnosti i savojnog naprezanja na granici proporcionalnosti te odnosa savojnog naprezanja na granici proporcionalnosti i modula loma

\begin{tabular}{|c|c|c|c|c|c|c|}
\hline \multirow{2}{*}{} & \multicolumn{3}{|c|}{ Location / Lokalitet } & \multicolumn{3}{c|}{ ANOVA } \\
\cline { 2 - 6 } & $\mathrm{S} 1$ & $\mathrm{~S} 2$ & GO & $F$ & $p$ & Post-hoc* $^{*}$ \\
\hline$\sigma_{\mathrm{s}}, \mathrm{MPa}$ & $95.10^{\mathrm{c}}$ & $89.96^{\mathrm{b}}$ & $84.23^{\mathrm{a}}$ & 17.16 & 0.0000 & 3 \\
\hline$E_{\mathrm{s}}, \mathrm{MPa}$ & $11647,47^{\mathrm{a}}$ & $12161.92^{\mathrm{a}}$ & $10566.23^{\mathrm{b}}$ & 8.18 & 0.0004 & 2 \\
\hline$\sigma_{\mathrm{sp}}, \mathrm{MPa}$ & $48.21^{\mathrm{b}}$ & $43.76^{\mathrm{a}}$ & $42.18^{\mathrm{a}}$ & 19.53 & 0.0000 & 2 \\
\hline$P_{\sigma}, \%$ & $50.88^{\mathrm{a}}$ & $49.03^{\mathrm{a}}$ & $50.57^{\mathrm{a}}$ & 2.04 & 0.1320 & 1 \\
\hline
\end{tabular}

*Number of homogeneous groups by Duncan's test / broj homogenih grupa prema Duncanovu testu

a, b,c Homogeneous groups / homogene grupe 


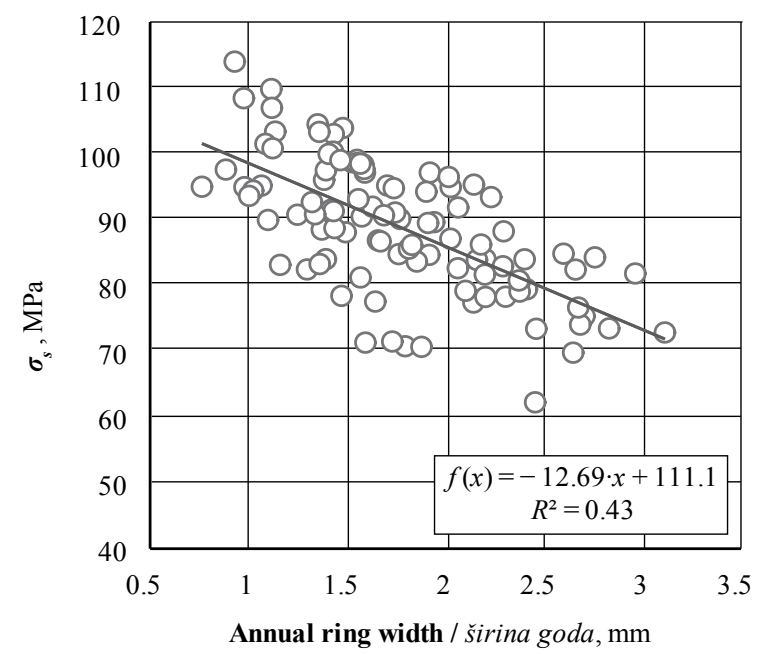

Figure 2 Dependence of $M O R$ and $M O E$ on annual ring width Slika 2. Ovisnost modula loma i modula elastičnosti o širini goda

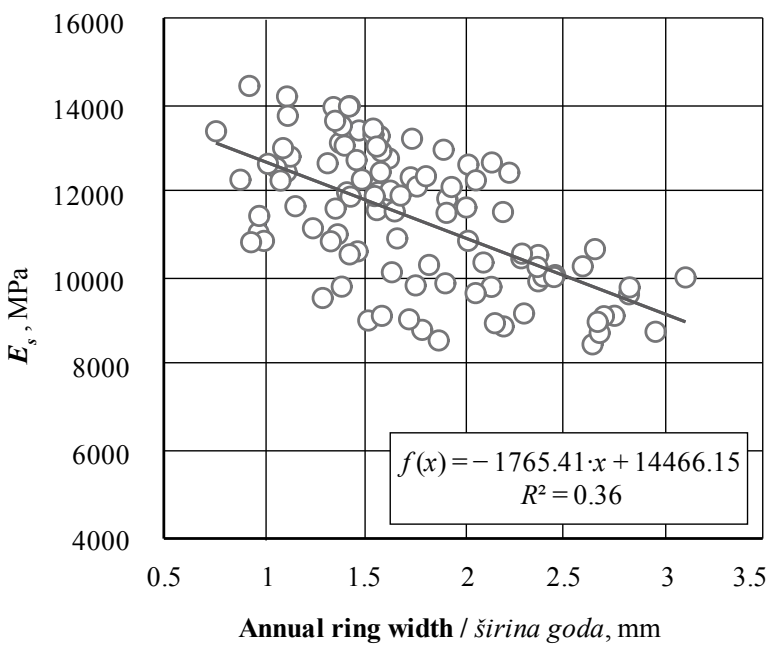

case, as the density of wood increases, the bending strength also increases, which is confirmed by this research (Figure 4). As wood density of Serbian spruce grows, so does the modulus of elasticity, although these correlations are slightly smaller than the correlations between density and MOR. In their study, Raiskila et al. (2006) state that the same is the case with spruce wood.

In order to obtain a model for strength estimation, the regression analysis included the dependence of $M O R$ on annual ring width and wood density. Multiple regression equation (Function 8) was obtained by stepwise multiple regression method. The parameters of the obtained equation and the regression characteristics (Table 8) show that there is a pronounced dependence of $M O R$ on the included elements. All regression coefficients are statistically significant at the $p<0.001$ level, as is the regression as a whole. On the basis of the coefficient of determination, $33 \%$ of the variation of the $M O R$ value is explained by the variation of the observed elements.

$$
\sigma_{s}=a+b \cdot a r w^{2}+c \cdot \rho^{2}
$$

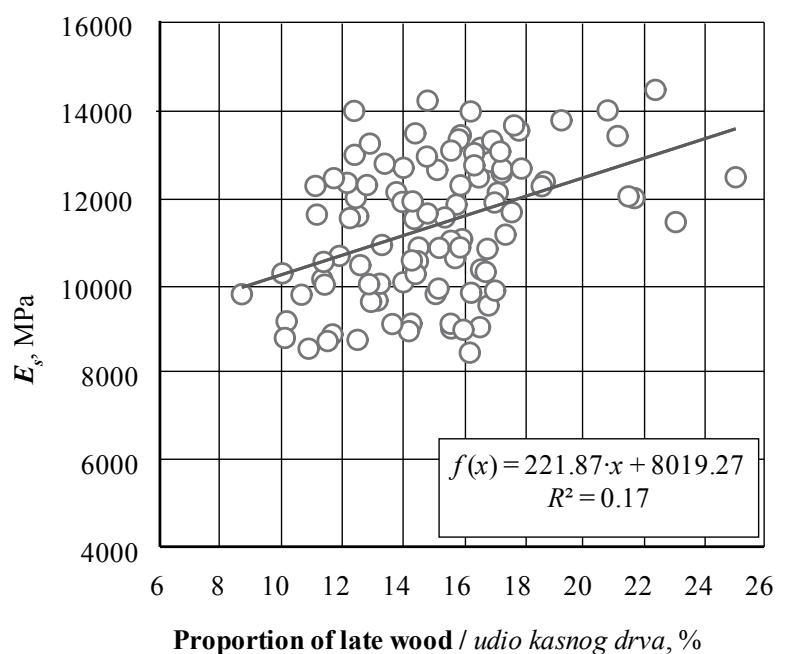

Figure 3 Dependence of $M O R$ and $M O E$ on proportion of late wood Slika 3. Ovisnost modula loma i modula elastičnosti o udjelu kasnog drva 

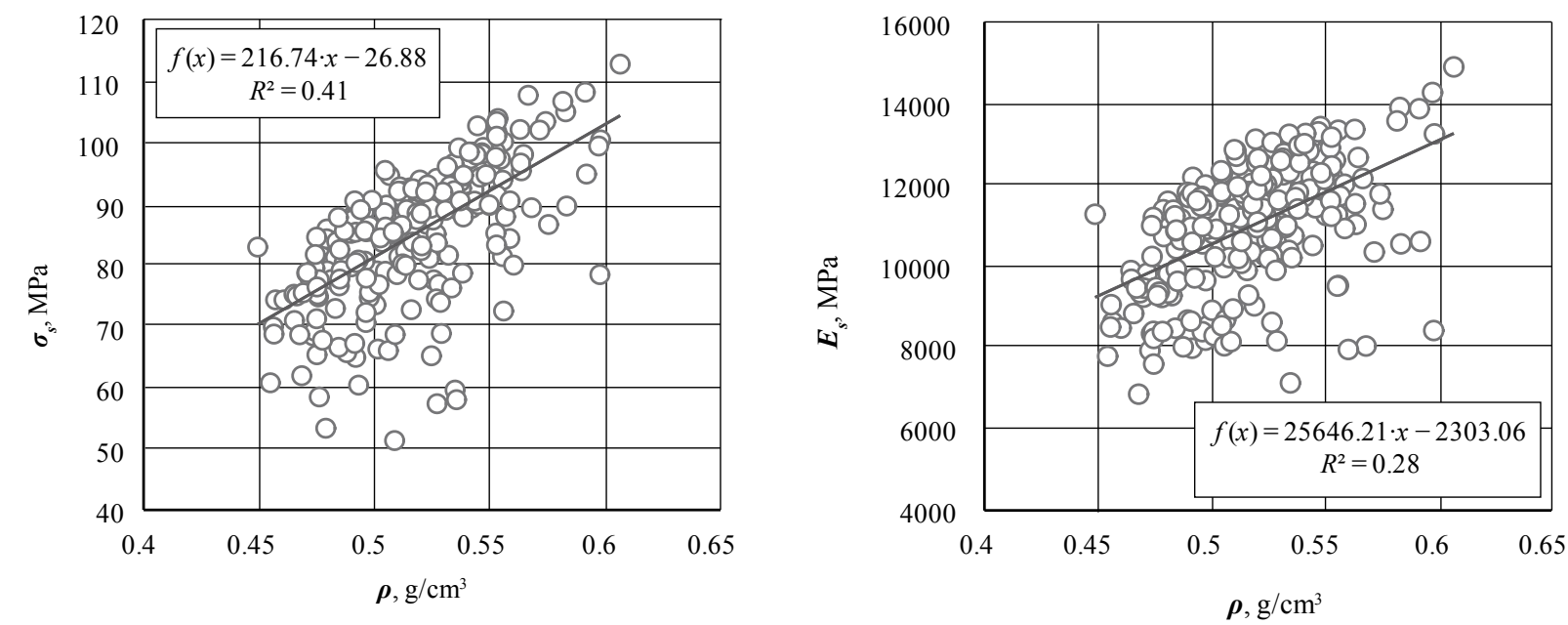

Figure 4 Dependence of $M O R$ and $M O E$ on wood density at the moment of testing

Slika 4. Ovisnost modula loma i modula elastičnosti o gustoći drva u trenutku ispitivanja

Generally, the $M O E$ is considered the most important strength predictor parameter (Baar et al., 2015). Investigating the correlation between $M O R$ and $M O E$ in spruce, Johansson and Kliger (2000) found that the coefficient of determination was 0.51 . The equation of relation between bending strength and modulus of elasticity reported by Johansson et al. (1992) is:

$$
\sigma_{s}=0.00383 \cdot E_{s}-2.4
$$

The dependence of $M O R$ on $M O E$ examined in this paper can be seen in Figure 5. The correlation is linear and positive, and based on the correlation coefficient of 0.77 , it can be concluded that the correlation is very strong.

\section{CONCLUSIONS 4. ZAKLJUČAK}

The results obtained in this paper have substantially improved the knowledge of certain mechanical properties of Serbian spruce from the territory of Bosnia and Herzegovina. It can be observed that Serbian spruce

Table 8 Regression characteristics (dependence of MOR on annual ring width and wood density at the moment of testing) Tablica 8. Obilježja regresije (ovisnost modula loma o širini goda i gustoći drva u trenutku ispitivanja)

\begin{tabular}{|c|c|c|c|c|c|c|c|c|c|c|}
\hline \multicolumn{2}{|c|}{$\begin{array}{c}\text { Regression coefficient } \\
\text { Koeficijent regresije }\end{array}$} & $\begin{array}{c}\text { Std. Err. of coeff. } \\
\text { Standardna pogreška } \\
\text { koeficijenta }\end{array}$ & $t$ & $p$ & $S_{\mathrm{e}}, \mathbf{m m}$ & $R$ & $R^{2}$ & $F$ & $p$ & $n$ \\
\hline $\mathrm{a}$ & 60.1964 & 10.77431 & 5.58703 & 0.000000 & \multirow{3}{*}{9.25774} & \multirow{3}{*}{0.58} & \multirow{3}{*}{0.33} & \multirow{3}{*}{25.42762} & \multirow{3}{*}{0.0000} & \multirow{3}{*}{101} \\
\hline $\mathrm{b}$ & -2.0408 & 0.56226 & -3.62969 & 0.000453 & & & & & & \\
\hline $\mathrm{c}$ & 111.4477 & 36.67212 & 3.03903 & 0.003043 & & & & & & \\
\hline
\end{tabular}

$S_{\mathrm{e}}$ - standard error of regression / standardna pogreška regresije, $R$ - correlation coefficient / koeficijent korelacije, $R^{2}-$ determination coefficient / koeficijent determinacije

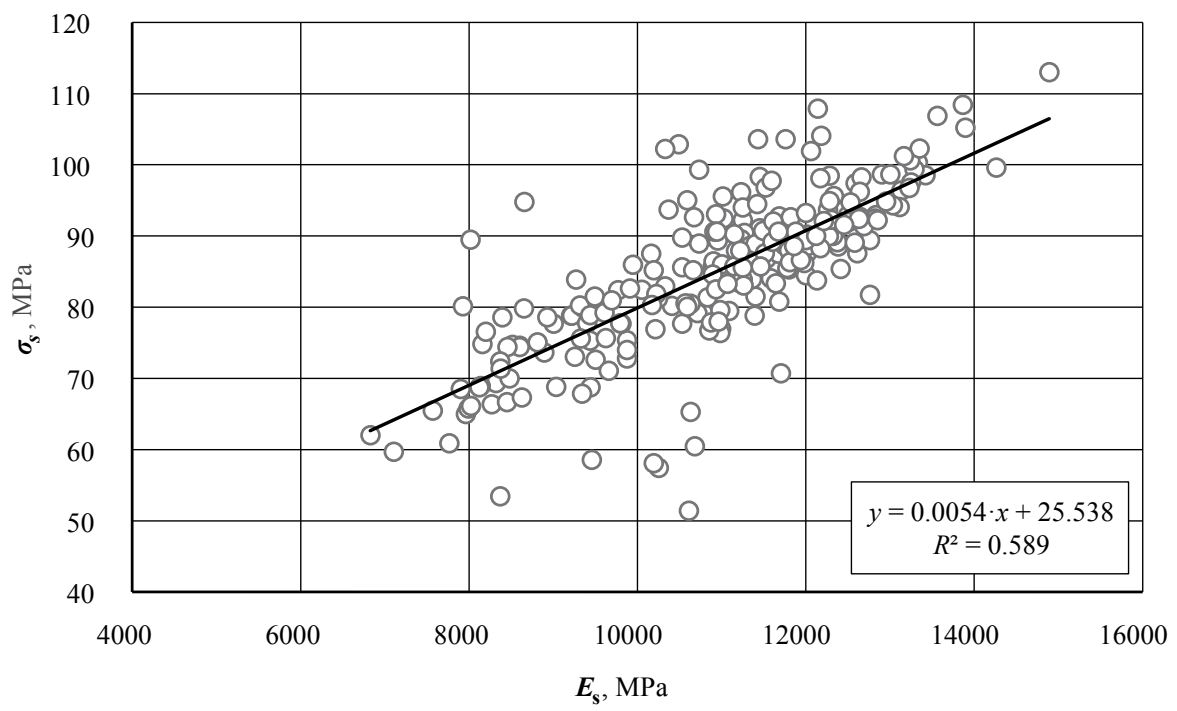

Figure 5 Dependence of $M O R$ on $M O E$

Slika 5. Ovisnost modula loma o modulu elastičnosti 
has quite high values of $M O R$ and $M O E$. Serbian spruce is known to be a protected species and not industrially significant. However, given its good mechanical properties, consideration should be given to establishing larger surfaces of planted forests with the aim of using Serbian spruce wood as a technical wood. Since there is a correlation between the width of the annual rings and $M O R$, care should be taken to achieve optimum growth in establishing and managing the new forest.

The modulus of elasticity may be a good predictor for determining the bending strength, given the very strong correlation between these two parameters.

\section{REFERENCES}

\section{LITERATURA}

1. Aanerød, R. S., 2014: Modeling density and mechanical properties in norway spruce (Picea abies (L.) Karst) by forest inventory data. Master Thesis, Norwegian University of Life Sciences Department of Ecology and Natural Resource Management.

2. Aleksić, M. J.; Geburek, T., 2010: Mitochondrial DNA reveals complex genetic structuring in a stenoendemic conifer Picea omorika [(Panč.) Purk.] caused by its long persistence within the refugial Balkan region. Plant Systematics and Evolution, 285: 1-11. https://doi.org/10.1007/s00606-009-0250-0.

3. Aleksić, M. J.; Geburek, T., 2014: Quaternary population dynamics of an endemic conifer, Picea omorika, and their conservation implications. Conservation Genetics, 15: 87-107. https://doi.org/10.1007/s10592-013-0523-6.

4. Alteyrac, J.; Cloutier, A.; Ung, C.-H.; Zhang, S. Y., 2006: Mechanical properties in relation to selected wood characteristics of Black spruce. Wood and Fiber Science, 38 (2): 229-237.

5. Baar, J.; Tippner, J.; Rademacher, P., 2015: Prediction of mechanical properties - modulus of rupture and modulus of elasticity - of five tropical species by nondestructive methods. Maderas. Ciencia y tecnología, 17 (2): 239252.https://doi.org/10.4067/s0718-221x2015005000023.

6. Bodig, J.; Jayne, B. A., 1982: Mechanics of wood and wood composites. Van Nostrand Reinhold, New York.

7. Čolić, D., 1953: Stanište Pančićeve omorike na desnoj strani Drine. Naučna knjiga. Beograd

8. Colić, D., 1957: Neki pionirski karakteri Pančićeve omorike i njena uloga u sukcesiji biljnih zajednica. Arhiv bioloških nauka br. 9. Beograd.

9. Fukarek, P., 1935: Picea omorika, njezina vrijednost u šmarstvu i pitanje njenog areala. Šumarski list. Zagreb.

10. Fukarek, P., 1950: Današnje rasprostranjenje Pančićeve omorike (Picea omorika Panč.) i neki podaci o njenim sastojinama. Godišnjak Biološkog instituta u Sarajevu, god. III, sv. $1-2$. Sarajevo.

11. Gorišek, Z.; Straže, A.; Pervan, S., 2004: Juvenile wood in spruce (Picea abies Karst.) - limitation of use: comparison of physical and mechanical properties between juvenile and adult wood. In: Proceedings of International conference Wood in the construction industry: rational utilisation of wood (ed. Jambreković, V.), Zagreb, Croatia, pp. 27-34.

12. Johansson, C.-J.; Brundin, J.; Gruber, R., 1992: Stress grading of Swedish and German timber. A comparison of machine stress grading and three visual grading systems. Swedish National Testing and Research Institute BuildingTechnology, SP Report: 23.
13. Johansson, M.; Kliger, R., 2000: Variability in strength and stiffness of structural Norway Spruce timber - influence of raw material parameters. In: Proceedings of World Conference on Timber Engineering Whistler Resort, British Columbia, Canada.

14. Karahasanović, A., 1992: Nauka o drvetu. Svjetlost, Sarajevo, pp. 426.

15. Kommert, R., 1993: Die Holzeigenschaften der Serbischen Fichte aus Anbauten im Freistaat Sachsen. Holzals Rob- und Werkstoff, 51, 329-334. https://doi.org/10.1007/BF02663804.

16. Lukić-Simonović, N., 1955: O osnovnim fizičkim svojstvima i njihovom međusobnom odnosu kod Picaae omorice Pančić. Glasnik Šumarskog fakulteta 10, Univerzitet u Beogradu, 237-266.

17. Lukić-Simonović, N., 1970: Uporedna istraživanja tehnoloških svojstava drveta Picea omorica Panč. i Picea excelsa Lin. u vezi sa uticajem staništa. Doktorska disertacija, Glasnik Šumarskog fakulteta, Univerzitet u Beogradu, Beograd.

18. Mataruga, M.; Isajev, V.; Gardner, M.; Christian, T.; Thomas, P., 2011: Picea omorika. The IUCN Red List of Threatened Species 2011: e.T30313A9532613.

19. Mataruga, M.; Piotti, A.; Daničić, V.; Cvjetković, B.; Fussi, B.; Konnert, M.; Vendramin G. G.; Aleksić, J. M., 2020: Towards the dynamic conservation of Serbian spruce $(P i-$ cea omorika) western populations. Annals of Forest Science 77, 1. https://doi.org/10.1007/s13595-019-0892-1.

20. Panshin, A. J.; de Zeeuw, C., 1980: Textbook of Wood Techonology, $4^{\text {th }}$ ed., McGrawHill, New York.

21. Popović, Z., 1990: Utjecaj vlažnosti i temperature na modul elastičnosti i savitljivost bukovog drveta. Magistarski rad. Šumarski fakultet Univerziteta u Beogradu.

22. Pushinskis, V.; Priedkalns, G.; Dolacis, J.; Hrols, J., 2002: Selected mechanical properties of Norway spruce wood in Latvia. Wood Structure and Properties '02, (eds. Kúdela, J.; Kurjatko, S.; Kúdela. J.). Arbora Publishers, Zvolen, Slovakia, pp. 157-159.

23. Raiskila, S.; Saranpää, P.; Fagerstedt, K.; Laakso, T.; Löija, M.; Mahlberg, R.; Paajanen, L.; Ritschkoff, A.-C., 2006: Growth rate and wood properties of Norway spruce cutting clones on different sites. Silva Fennica, 40 (2): 341. https://doi.org/10.14214/sf.341.

24. Svoboda, T.; Gaffová, Z.; Rajnoha, R.; Šatanová, A.; Kminiak, R., 2017: Bending forces at the proportionality limit and the maximum - technological innovations for better performance in wood processing companies. BioResources, 12 (2): 4146-4165. https://doi.org/10.15376/biores.12.2.4146-4165.

25. Šoškić, B.; Popović, Z., 2002: Svojstva drveta. Šumarski fakultet Beograd, Serbia, pp. 298.

26. Vasilj, Đ., 2000: Biometrika i eksperimentiranje u bilinogojstvu. Hrvatsko agronomsko društvo, Zagreb, Croatia, pp. 109.

27. Vidaković, M.; Franjić, J., 2004: Golosjemenjače. Šumarski fakultet Sveučilišta u Zagrebu. Zagreb, Croatia.

28. ***ISO 3133, 1975: Wood - Determination of ultimate strength in static bending.

\section{Corresponding address:}

Assist. Prof. DANIJELA PETROVIĆ, PhD

University of Banja Luka

Faculty of Forestry

Vojvode Stepe Stepanovića 75a

78000 Banja Luka, BOSNIA AND HERZEGOVINA

e-mail: danijela.petrovic@sf.unibl.org 